\title{
EFEKTIVITAS PELATIHAN KONSELING KESEHATAN REPRODUKSI TERHADAP PENINGKATAN KOMPETENSI KADER POSYANDU DALAM PELAYANAN KONSELING PENCEGAHAN KANKER SERVIKS DI KABUPATEN KUNINGAN TAHUN 2018
}

\author{
Ai Nurasiah, Mala Tri Marliana \\ Program Studi Kebidanan STIKes Kuningan \\ 41nurasiah@gmail.com
}

\begin{abstract}
Abstrak
Masalah kesehatan reproduksi diantaranya kanker serviks yang merupakan penyebab kematian nomor dua pada perempuan di dunia setelah kanker payudara, sedangkan di Indonesia kanker serviks menduduki peringkat pertama. Sebanyak 15.000 kasus baru kanker leher rahim terjadi dengan angka kematian 7.500 kasus per tahun (Depkes RI,2015). Salah satu upaya untuk menekan tingginya kasus kanker serviks yaitu dengan memberikan konseling di tingkat dasar yaitu di masyarakat. Upaya ini bisa melibatkan kader posyandu, karena kader merupakan ujung tombak dalam kegiatan yang mendukung permasalahan kesehatan. Akan tetapi, sebagian besar kader posyandu kurang maksimal dalam melaksanakan perannya serta memiliki kendala dalam mentransformasi pengetahuannya kepada ibu - ibu peserta posyandu. Hal ini disebabkan karena pengetahuan yang kurang serta minimnya pelatihan atau pembinaan dari petugas kesehatan tentang cara memberikan konseling yang baik. Penelitian ini bertujuan untuk mengetahui efektivitas pelatihan konseling kesehatan reproduksi terhadap peningkatan kompetensi kader posyandu dalam upaya pencegahan kanker serviks di Kabupaten Kuninga. Adapun kompetensi yang diukur meliputi pengetahuan dan keterampilan.

Metode penelitian ini menggunakan quasi eksperimen dengan desain non equivalent comparison group design. Sampel penelitian ini adalah kader posyandu di Desa Bayuning sebanyak 40 orang (20 orang kelompok kontrol dan 20 orang kelompok eksperimen) dengan teknik pengambilan sampel secara total sampling. Teknik analisis data menggunakan Paired T-Tes.

Hasil analisis bivariat didapatkan bahwa ada perbedaan pengetahuan pada kelompok kontrol sebelum dan sesudah penelitian $(\mathrm{p}=0,014)$, ada perbedaan keterampilan pada kelompok kontrol sebelum dan sesudah penelitian $(\mathrm{p}=0,025)$. Ada perbedaan pengetahuan pada kelompok eksperimen sebelum dan sesudah penelitian ( $p=0,006)$, ada perbedaan keterampilan pada kelompok eksperimen sebelum dan sesudah penelitian $(\mathrm{p}=0,008)$.

Diharapkan kader posyandu dapat memberikan konseling kepada seluruh wanita usia subur agar dapat mencegah kejadian kanker serviks serta begitu juga pihak puskesmas dapat melakukan pendampingan secara rutin terhadap kompetensi kader posyandu dan mengadakan pemeriksaan deteksi dini kanker serviks.
\end{abstract}

Kata Kunci : pengetahuan, dan keterampilan konseling kader posyandu 
JURNAL ILMU KESEHATAN BHAKTI HUSADA:

HeALTH SCIENCES JOURNAL, Vol. 09 No. 02, DeSEMBER 2018 DOI: https://doi.org/10.34305/jikbh.v9i2.65

\section{Pendahuluan}

Masalah kesehatan reproduksi di Indonesia masih menjadi sorotan utama dan tantangan bagi pemerintah karena mempunyai dampak yang sangat luas dan menyangkut berbagai aspek kehidupan serta menjadi parameter kemampuan negara dalam menyelenggarakan pelayanan kesehatan terhadap masyarakat. Masalah kesehatan reproduksi diantaranya kanker serviks yang merupakan penyebab kematian nomor dua pada perempuan di dunia setelah kanker payudara, sedangkan di Indonesia kanker serviks menduduki peringkat pertama. Sebanyak 52 juta perempuan Indonesia berisiko terkena kanker serviks, sementara 36 persen perempuan dari seluruh penderita kanker adalah pasien kanker serviks. Sebanyak 15.000 kasus baru kanker leher rahim terjadi dengan angka kematian 7.500 kasus per tahun (Depkes RI,2015).

Hasil studi pendahuluan pada Bulan Februari 2017 di Desa Bayuning Kabupaten Kuningan kepada 6 orang wanita usia subur, didapatkan 4 orang belum mengetahui tentang pencegahan kanker serviks. Konseling kesehatan merupakan suatu upaya untuk meningkatkan pengetahuan masyarakat khususnya perempuan. Upaya ini bisa melibatkan kader posyandu, karena kader merupakan ujung tombak dalam kegiatan yang mendukung permasalahan kesehatan serta kader berasal dari masyarakat itu sendiri, sehingga mereka mampu bergerak secara luas dan luwes (Trisnawati dan Rahayuningsih, 2008).

Hasil wawancara dengan 5 orang kader posyandu di Desa Bayuning Kabupaten Kuningan, sebagian besar mereka melakukan pelayanan kepada balita tidak pernah memberikan konseling kesehatan reproduksi termasuk pencegahan kanker serviks serta memiliki kendala dalam mentransformasi pengetahuannya kepada ibu - ibu. Hal tersebut disebabkan karena pengetahuan yang kurang serta minimnya pelatihan atau pembinaan dari petugas kesehatan tentang cara memberikan konseling yang baik. Upaya peningkatan kapasitas kader posyandu dalam memberikan komunikasi dapat dilakukan pelatihan yang diharapkan kader posyandu kompeten dalam memberikan konseling sehingga memiliki pengetahuan baik serta terjadi perubahan perilaku dalam menjaga kesehatan reproduksi dan mampu mencegah penyakit kanker serviks. Oleh karena itu penulis merasa tertarik untuk meneliti tentang efektivitas pelatihan keterampilan konseling kesehatan reproduksi terhadap peningkatan kompetensi kader posyandu dalam upaya pencegahan kanker serviks.

\section{Metode}

Metode penelitian ini menggunakan quasi eksperimen dengan desain non equivalent comparison group design. Sampel penelitian ini adalah kader posyandu di Desa Bayuning sebanyak 40 orang (20 orang kelompok kontrol dan 20 orang kelompok eksperimen) dengan teknik pengambilan sampel secara total sampling. Teknik analisis data menggunakan Paired T-Tes.

\section{Hasil}

\section{Hasil Analisis Univariat}

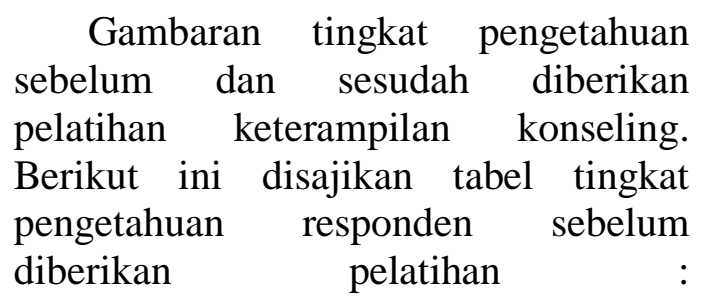


Tabel 4.1 Gambaran Tingkat Pengetahuan Responden Sebelum Diberikan Pelatihan

\begin{tabular}{lcccc}
\hline \multirow{2}{*}{$\begin{array}{c}\text { Tingkat } \\
\text { Pengetahuan }\end{array}$} & \multicolumn{4}{c}{ Kelompok Responden } \\
\cline { 2 - 5 } & \multicolumn{2}{c}{ Kontrol } & \multicolumn{3}{c}{ Eksperimen } \\
\hline Kurang & $\mathrm{f}$ & $\%$ & $\mathrm{f}$ & $\%$ \\
\hline Cukup & 4 & $20 \%$ & 6 & $30 \%$ \\
\hline Baik & 9 & $45 \%$ & 6 & $30 \%$ \\
\hline Total & 7 & $35 \%$ & 8 & $40 \%$ \\
\hline
\end{tabular}

Berdasarkan tabel 4.1 diketahui bahwa dari 20 responden kelompok kontrol sebagian besar $(45 \%)$ memiliki pengetahuan cukup. Sedangkan dari 20 responden kelompok eksperimen sebagian besar (40\%) memiliki pengetahuan baik. Berikut ini disajikan tabel tingkat pengetahuan responden setelah diberikan pelatihan :

Tabel 4.2 Gambaran Tingkat Pengetahuan Responden Setelah Diberikan Pelatihan

\begin{tabular}{lcccc}
\hline \multirow{2}{*}{$\begin{array}{c}\text { Tingkat } \\
\text { Pengetahuan }\end{array}$} & \multicolumn{4}{c}{ Kelompok Responden } \\
\cline { 2 - 5 } & \multicolumn{2}{c}{ Kontrol } & \multicolumn{3}{c}{ Eksperimen } \\
\hline Kurang & $\mathrm{f}$ & $\%$ & $\mathrm{f}$ & $\%$ \\
\hline Cukup & 1 & $5 \%$ & - & - \\
\hline Baik & 6 & $30 \%$ & 6 & $30 \%$ \\
\hline Total & 13 & $65 \% \%$ & 14 & $70 \%$ \\
\hline
\end{tabular}

Berdasarkan tabel 4.2 diketahui bahwa dari 20 responden kelompok kontrol sebagian besar $(65 \%)$ memiliki pengetahuan baik. Sedangkan dari 20 responden kelompok eksperimen sebagian besar memiliki pengetahuan baik $(70 \%)$ dan tidak ada satupun yang memiliki pengetahuan kurang.

Gambaran keterampilan konseling sebelum dan sesudah diberikan pelatihan keterampilan konseling Berikut ini disajikan tabel keterampilan responden sebelum diberikan pelatihan :

Tabel 4.5 Gambaran Keterampilan Konseling Sebelum Diberikan Pelatihan

\begin{tabular}{|c|c|c|c|c|}
\hline \multirow{3}{*}{ Keterampilan } & \multicolumn{4}{|c|}{ Kelompok Responden } \\
\hline & \multicolumn{2}{|c|}{ Kontrol } & \multicolumn{2}{|c|}{ Eksperimen } \\
\hline & $\mathrm{f}$ & $\%$ & $\mathrm{f}$ & $\%$ \\
\hline Kurang & 10 & $50 \%$ & 11 & $55 \%$ \\
\hline Baik & 10 & $50 \%$ & 9 & $45 \%$ \\
\hline Total & 20 & $100 \%$ & 20 & $100 \%$ \\
\hline
\end{tabular}

Berdasarkan tabel 4.5 diketahui bahwa dari 20 responden kelompok kontrol sebanyak $50 \%$ memiliki keterampilan kurang dan baik. Sedangkan dari 20 responden kelompok eskperimen sebagian besar memiliki keterampilan konseling baik $(55 \%)$.

Berikut ini disajikan tabel keterampilan responden sesudah diberikan pelatihan : 
Tabel 4.6 Gambaran Keterampilan Konseling Sesudah Diberikan Pelatihan

\begin{tabular}{|c|c|c|c|c|}
\hline \multirow{3}{*}{ Keterampilan } & \multicolumn{4}{|c|}{ Kelompok Responden } \\
\hline & \multicolumn{2}{|c|}{ Kontrol } & \multicolumn{2}{|c|}{ Eksperimen } \\
\hline & $\mathrm{f}$ & $\%$ & f & $\%$ \\
\hline Kurang & 5 & $25 \%$ & 4 & $20 \%$ \\
\hline Baik & 15 & $75 \%$ & 16 & $80 \%$ \\
\hline Total & 20 & $100 \%$ & 20 & $100 \%$ \\
\hline
\end{tabular}

Berdasarkan tabel 4.6 diketahui bahwa dari 20 responden kelompok kontrol sebagian besar memiliki keterampilan baik $(75 \%)$. Begitupun dari 20 responden kelompok eksperimen sebagian besar memiliki keterampilan konseling baik (80\%).

\section{Hasil Analisis Bivariat}

Rata - Rata Tingkat Pengetahuan, dan Keterampilan Konseling pada kelompok Kontrol dan Eksperimen sebelum dan sesudah diberikan pelatihan di Desa Bayuning Kecamatan Kadugede Kabupaten Kuningan Tahun 2018

\begin{tabular}{|c|c|c|c|c|c|c|}
\hline \multirow{2}{*}{ Variabel } & \multicolumn{3}{|c|}{ Kontrol } & \multicolumn{3}{|c|}{ Eksperimen } \\
\hline & $\mathrm{n}$ & Rata \pm s.d & Nilai p & $\mathrm{n}$ & Rata \pm s.d & Nilai p \\
\hline \multicolumn{7}{|c|}{ Tingkat Pengetahuan } \\
\hline $\begin{array}{l}\text { Sebelum } \\
\text { pelatihan (Pre } \\
\text { Tes) }\end{array}$ & 20 & $2,1 \pm 0,745$ & 0,014 & 20 & $2,10 \pm 0,852$ & 0,006 \\
\hline $\begin{array}{l}\text { Sesudah } \\
\text { pelatihan (Post } \\
\text { Tes) }\end{array}$ & 20 & $2,6 \pm 0,598$ & & 20 & $2,70 \pm 0,470$ & \\
\hline \multicolumn{7}{|l|}{ Keterampilan } \\
\hline $\begin{array}{l}\text { Sebelum (Pre } \\
\text { Tes) }\end{array}$ & 20 & $1,50 \pm 0,513$ & 0,025 & 20 & $1,45 \pm 0,510$ & 0,008 \\
\hline $\begin{array}{l}\text { Sesudah (Post } \\
\text { Tes) }\end{array}$ & 20 & $1,75 \pm 0,444$ & & 20 & $1,80 \pm 0,410$ & \\
\hline
\end{tabular}

Sumber : hasil pengolahan data (2018)

\section{Pembahasan}

Berdasarkan hasil penelitian didapatkan bahwa pengetahuan kader posyandu tentang kanker serviks pada kelompok kontrol sebelum pre tes sebagian besar memiliki pengetahuan cukup (45\%) sedangkan pada kelompok eksperimen sebagian besar memiliki pengetahuan baik (40\%). Tingkat pengetahuan kader posyandu setelah dilakukan post tes pada kelompok kontrol sebagian besar memiliki pengetahuan baik $(65 \%)$ begitu pada kelompok eksperimen sebagian besar memiliki pengetahuan baik $(70 \%)$ dan hasil uji beda didapatkan nilai $\mathrm{p}=0,006$ dengan demikian terdapat perbedaan yang bermakna antara skor tingkat pengetahuan sebelum dan sesudah diberikan pelatihan.

Hasil penelitian tersebut sejalan dengan penelitian Sianturi, dkk tahun 2012 yang menunjukkan terdapat peningkatan pengetahuan kader posyandu tentang deteksi dini tumbuh kembang balita dengan peningkatan mean sebesar 23.32 poin dengan selisih nilai standar deviasi 1.07, sedangkan pada kelompok kontrol didapatkan peningkatan nilai mean sebesar 21.9 poin. Begitu juga diperkuat oleh hasil penelitian Gilang dan Suratini tahun 2014 yang menunjukkan nilai rata - rata pengetahuan kader sebesar 3.6842 dan sesudah pelatihan kader sebesar 3.9474 dan nilai signifikasi 0,025 dapat disimpulkan 
JURNAL ILMU KESEHATAN BHAKTI HUSADA:

HeALTH SCIENCES JOURNAL, Vol. 09 No. 02, DESEMBER 2018 DOI: https://doi.org/10.34305/jikbh.v9i2.65

bahwa ada pengaruh pelatihankader terhadap pengetahuan kader dalam pengelolaan posyandu.

Hal tersebut juga didukung oleh teori Notoatmodjo (2003) bahwa pengetahuan merupakan hasil dari tahu dan ini terjadi setelah orang melakukan pengindraan terhadap suatu objek tertentu. Pengindraan terjadi melalui panca indera penglihatan, pendengaran, penciuman, rasa dan raba. Sebagian besar pengetahuan manusia diperoleh melalui mata dan telinga. Dengan demikian peningkatan pengetahuan pada kelompok perlakuan diakibatkan karena adanya intervensi pelatihan yang telah diberikan.

Hasil penelitian juga didapatkan bahawa sebagian besar pada kelompok kontrol memiliki pengetahuan cukup dan pada kelompok eksperimen memiliki pengetahuan. Hal tersebut dapat disebabkan adanya pengetahuan yang telah dimiliki oleh responden sebelumnya baik didapat dari media elektronik maupun pengalaman pribadi dan sharing dengan teman, dan pernah mendapatkan materi kanker serviks sebelumnya sehingga mampu mengingat kembali materi pelatihan yang telah dipelajari sebelumnya. Hal tersebut sesuai dengan pendapat Morton et al. (1995), bahwa pengetahuan merupakan hasil stimulasi informasi yang diperhatikan dan diingat. Sarwono (2004), juga berpendapat bahwa informasi yang telah diberikan dengan pendekatan komunikasi interpersonal/konseling mengenai kesehatan reproduksi akan meningkatkan pengetahuan seseorang.

\section{Kesimpulan}

1. Terdapat perbedaan yang bermakna antara tingkat pengetahuan responden saat pre tes dan post tes pada kelompok kontrol dengan nilai $\mathrm{p}=0,014$

2. Terdapat perbedaan yang bermakna antara keterampilan konseling responden saat pre tes dan post tes pada kelompok kontrol dengan nilai $p=0,025$
3. Terdapat perbedaan yang bermakna antara tingkat pengetahuan responden saat pre tes dan post tes pada kelompok eksperimen dengan nilai $\mathrm{p}=0,006$

4. Terdapat perbedaan yang bermakna antara keterampilan konseling responden saat pre tes dan post tes pada kelompok eksperimen dengan nilai $\mathrm{p}=0,008$

\section{Daftar Pustaka}

Arikunto,S. 2006. Prosedur Penelitian Suatu Pendekatan Praktik.Edisi VI. Jakarta : Rhineka Cipta

Diananda, R., 2009. Kanker Serviks: Sebuah Peringatan Buat Wanita. In: Diananda, R. Mengenal Seluk-Beluk Kanker. Yogyakarta: Katahari, 43-60.

Edianto, D., 2006. Kanker Serviks. In: Aziz, M.F., Andrijono, Saifuddin, A.B., ed. Buku Acuan Nasional Onkologi Ginekologi. Jakarta: Yayasan Bina Pustaka Sarwono Prawirohardjo, 442-454.

Fitri H dan Mardiana. 2011. Keterampilan kader posyandu sebelum dan sesudah pelatihan.

http://journal.unes.ac.id/index.php/kem as

Gunanti I, dkk. Pemberdayaan Kader Posyandu Melalui Penerapan Metode Konseling Gizi Dalam Upaya Meningkatkan Kualitas Pembinaan Program Keluarga Sadar Gizi.

Hernawan, dkk .(2016). Efektifitas Pelatihan Konseling Dan Penyusunan Menu Mp-Asi Terhadap Keterampilan Kader Dalam Mendampingi Ibu. Jurnal Vokasi Kesehatan Volume 2 no 1. Januari 2016

Kemenkes RI. 2014. Kesehatan Reproduksi dan Seksual Bagi Calon Pengantin. Jakarta.

Kumalasari dan Andhayantoro .2012 . Kesehatan Reproduksi untuk Mahasiswa Kebidanan dan Keperawatan. Jakarta: Salemba Medika, hal 23. 
Lestari, H. 2011. Kesehatan Reproduksi Modul Mahasiswi. Jakarta : Yayasan Pendidikan Kesehatan Perempuan

Notoatmodjo, S. 2007. Promosi Kesehatan dan Ilmu Perilaku. Jakarta : Rineka Cipta

Pharadibha, dkk. 2012. Pengaruh Pelatihan terhadap Keterampilan Kader dalam Pembuatan PTM Modisco di Wilayah Kerja Puskesmas Pematang Panjang Kecamatan Air Putih Kabupaten Batubara Tahun 2012. http://jurnal.usu.ac.id/index.php/gkre/ar ticle/view/1137/593. Vol 1 (2012)
Rasjidi, I., 2008. Kanker Serviks. In: Rasjidi, I., ed. Manual Prakanker Serviks. Jakarta: Sagung Seto, 5-22.

Sukawati. 2014. Kesehatan Reproduksi dan Keluarga Berencana dalam Tanya Jawab. Jakarta : Rajawali. Hal. 88.

Trisnawati, A.G. dan Rahayu, F.B. 2008. Pelatihan Peningkatan Kemampuan Kader Kesehatan Dalam Penanganan Tuberkulosis (tbc). di Wilayah Kerja Puskesmas Gemolong II Sragen. WARTA, Vol .11, No. 2: 150 - 158. 